\title{
Treatment of hypersensitivity
} pneumonitis: Contact avoidance
versus corticosteroid treatment

\author{
YVON CORMIER MD, MARC DESMEULES MD \\ Unité de Recherche, Centre de pneumologie, Hôpital et Université Laval, Québec
}

Y CoRmier, M Desmeules. Treatment of hypersensitivity pneumonitis: Comparison of contact avoidance with corticosteroid treatment. Can Respir J 1994;1(4):223-228.

OB.JECTIVE: To compare the early response to oral enticosteroid treatment with contact avoidance in patients with icutc hypersensitivity pneumonitis.

DEsign: Prospective evaluation of palticnts with hypersensitivity pneumonitis, who chose either contact avordance or low dose corticosteroid treatment.

Study Population: Twenty-eight patients with icutc hypersensitivity pneumonitis.

INTERVENTIONS: Each subject had a clinical evaluation, chest radiographs, lung function measurements and at bronchoalveolar lavage at diagnosis and after one month of cither form of treatment (contact avoidance or oral prednisone $20 \mathrm{mg}$ daily).

RESuLTS: Nineteen subjects (all with farmer's lung) chose the corticosteroid arm and nine chose the contact avoidance arm (three farmer's lung, four humidifier lung and two bird fancier's lung). Initially subjects in both groups had similar disease severity (single breath carbon dioxide diffusion capacity [DLCO] 61.4 \pm 3.9 and $60.7 \pm 18.9 \%$ predicted, respectively /mean $\pm \mathrm{SD}$, total bronchoalveolar lavage cells $\left[01 \times 10^{6}\right.$ versus $119 \times 10^{6}$ ). All subjects improved with either treatment, and 10 subjects considered themselves back to normal. DLCO increased from the above values to $74.6 \pm 21.9$ and $77.1 \pm 18.5$, respectively. Bronchoalveolar lavage lymphocytosis remained unchanged after one month of either treatment.

Conclusions: Both low dosc oral corticosteroids and entact avoidance provided adequate initial treatment of acute hypersensitivity pneumonitis. Bronchoalveolar lavage cellular findings remaned abnormal duspite clinical improvement; this technique did not provide useful clinical information in the follow-up of hypersensitivity pneummonitis.

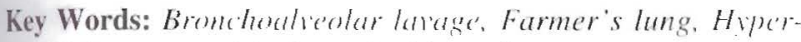
sensitivity pneumonitis, laterstitul lung disease

\section{Traitement de la pneumopathie d'hypersensi- bilité : Comparaison de la suppression de l'ex- position avec la corticothérapie}

Oв.естиғ : Comparer la réponse initiale d'une corticothérapie par voie orale à celle d'une suppression de l'exposition à l'antigène chez des patients souffrant d'une pneumopathie d'hypersensibilité aiguë. MoDĖLE: Évaluation prospective de patients souffrant d'une pneumopathie d'hypersensibilité qui ont choisi, soit de ne plus s'exposer à l'antigène, soit de suivre un traitement par corticostérö̈des à faibles doses. Population a L'Étude: Vingt-huit patients souffrant d'une pneumopathie d'hypersensibilité.

INTERVENTIONS: Chaque sujet a subi une évaluation clinique, des radiographies pulmonaires, des épreuves de fonction respiratoire et un lavage broncho-alvéolaire au moment du diagnostic et 1 mois après l'une ou l'autre forme de traitement (suppression de l'exposition ou 20 $\mathrm{mg} /$ jour de prednisone par voie orale).

RÉsultats : Dix neuf sujets (tous atteints du poumon du fermier) ont choisi l'aide des corticostéroüdes et 9 sujets ont choisi d'éviter l'exposition (trois atteints du poumon du fermier, quatre de la maladie des humidificateurs et deux de la maladie des éleveurs d'oiseaux). Initialement, la gravité de la maladie était la même pour les sujets des deux groupes (capacité de diffusion du monoxyde de carbone par la méthode en apnée $\left[\mathrm{T}_{\mathrm{L}}, \mathrm{CO}, \mathrm{sb}\right] 61,4 \pm 3,9 \%$ et $60,7 \pm 18,9 \%$ de la valeur théorique, respectivement [moyenne \pm écart-type], et nombre total des cellules dans le lavage broncho-alvéolaire $101 \times 10^{6}$ cellules contre $119 \times 10^{6}$ cellules). L'état des sujets s'est amélioré avec chacun des traitemcnts. et 10 sujets ont considéré que leur état était redevenu normal. La $\mathrm{T}_{1}$.cossb comparativement aux valeurs antérieures était respectivement de $74,6 \pm 21,9 \%$ et $77.1 \pm 18,5 \%$. La lymphocytose dans le lavage broncho-alvéolaire est restée inchangée après un mois de l'un ou l'autre des traitements.

Conclusion : Les corticostérö̈des administrés oralement à faibles doses et la suppression de l'exposition sont tous dux des traitements initiaux adéquats de la pneumopathie d'hypersensibilité. Les résultats d. l'analyse du lavage broncho-alvéolaire restaient anormaux malgré une amélioration clinique ; cette technique n'a pas fourni d'informations clinigues utiles prour la suivi de la pneumopathie d’hypersensibilité. 
$\mathrm{H}$ YPERSENSTITITY PNLIMONITIS IS A DELAYED-TYPE allergic reation of the lunge in response to the inhalat tion of a varicty of foreign patticles, usually organic in nature (I). Acutely. the diseatse manilists itself by a febrile ratelion accompanied by dyspnea, cough and chest tightness $(2,3)$. These symploms usually oceur 3 to 8 h aller contact with the offending alleren and subside over the next 24 to 48 h if contact is averded. When possible, contact avoidance is the obvious treatment of choice for hypersensitivity pneumonitis. However, when the contalet cannot be avoided the ate manifestations can be controlled by systemic administration of corticosteroids. Although steroids control acute manifestations, their use does not modify the long term outcome of the discase $(4,5)$. It is our current practice to suggest contate avoidance ats the intiat treatment of hypersensitivity pneut monitis and, when this is not fatsible, we administer short courses ol orat eorticosteroids 1 o control the discase. It is not known which of these two approaches gives the best initial response, nor their effects on lung cells ats atsicssed by bronchoalveolar lavage (BAL). The present study was done to compate the short term effect of these two forms of treatment on the initial clinical, functional, radiological and $\mathrm{B} \triangle \mathrm{I}$, cell recovery in acute hypersensitivity pncumonitis. The results show that relatively small datily doses of oral corticosteroids are as effective ats contact avoidance in controlling acute disease. However, a matred bronchoalveolar lymphocytosis persists after one month of either form of tratment.

\section{PATIENTS AND METHODS}

The study population included 28 catses of alcule hypersensitivity pnemmonitis ol whom 22 had farmer"s lung, lour had humidificr lung and two had bird fancier's lung. There were 23 males and five lemales aged $42 \pm 12$ years (mean $\pm S D$ ), range 24 to 67 . Of the five females. 1 wo were in the prednisone group and three were in the contact avoidance group. Mean ages were similar for each group: prodnisone $40 \pm 11$ years and noncontik $47 \pm 13$ years. Twenty-six paticnts were nonsmokers and lwo were ex-smokers (longer than one year) The diagnosis was based on clinical, radiological, functional, BAL and serological criteria (6). Since some of these subjects could not avoid contact (ustailiy famers) they were not randomized into either am of the study. All subjects were encouraged (1) alvoid contact as the only form of initial trealment. Subjects who could not atvoid the oflending environment (19 subjects in this study) were given oral corticosteroids (20 $\mathrm{mg}$ of prednisone daily for one month); those who could cease contace received no other form of treatment $(n=-9)$.

All subjects were studied twice: at diagnosis and at the end of one month of either contact atvoidance or cortico steroid treatment. At cach visit all subjects had it clinical history and physical examination, lung function measure ments. posteroanterior and lateral chest films and BAL. Both lung function tests werc measured in the same laboratory on the sanc pulmonary function eyuipment. Tests obtained included: lung volumes by boly plethysmouraphy, forced expiratory thows and single breath carbon dioxide diffusion capacity (DLCO). Results are reported as a percentage of predicted values (7.8). All chest films were read blindly by one of the authors who is a certilied $B$ reader. lifms were scored an previously described (9). Bricfly, lung ficlds were subdivided into six regions: upper, middle and lower for each lung. Each of these regions was given at seore of () to 4 for the presence and intensity of infiltrates. With this system, nomal lunges have a score of () while a seore of 24 signilices marked difluse inliftaltes throughout both lung licelds. The BAL was done with $30(0 \mathrm{ml}$, of sterile nomal saline injected in six 50 $\mathrm{mL}$ aliquots, each instillation followed by gentle aspiration. The lavage fluid was kept on ice until centrifugation on cytospin. Cells were counted by Diff Quik (Baxter) and diflerentials obtained on Ciemsil and esterase stained preparations.

Statistical analysis: Data were analyzed using the statistical package SAS (SAS Institute Inc, North Carolina). Results were expressed as mean \pm SD for pulmonaly lunction and as mean $\pm S E M$ for the graphical represcontition of BAL cells Original data from the BAL cell analysis were transformed into ranks. Thus, for each variable. the observations were replaced by their ranks because no variance stabilising trans formation was encountered. Data from pulmonily functions were compared using an analysis of covariance on trans formed values where the concomitant variables are the initia values as they were correlated with their respective changes. The square root of each proportion was transloment to its are sine. Thus, the resultant data hatve an underlying distribution that is normal. All reported P values anc two-tailed and were considered significant if they were less than 0.05.

TABLE 1

Results of pulmonary functions at diagnosis (initial) and at one month follow-up (mean \pm SD) for subjects treated with oral corticosteroids (prednisone) or by contact avoidance

\begin{tabular}{|c|c|c|c|c|c|}
\hline & TLC & RV & FVC & $\mathrm{FEV}_{1}$ & DLCO \\
\hline \multicolumn{6}{|c|}{ Prednisone group } \\
\hline Initial & $95.0 \pm 14.6$ & $146.0 \pm 51.5$ & $73.4 \pm 13.1$ & $72.7+15.9$ & $61.4+17.1$ \\
\hline Follow-up & $99.1 \pm 15.8$ & $136.7 \pm 43.6$ & $82.6 \pm 12.9$ & $80.2+14.5$ & $74.9+21.3$ \\
\hline \multicolumn{6}{|c|}{ Avoidance group } \\
\hline Initial & $99.8 \pm 18.9$ & $134.4 \pm 66.2$ & $80.0 \pm 24.4$ & $81.4+22.9$ & $60.7+18.9$ \\
\hline Follow-up & $99.2 \pm 16.6$ & $114.7 \pm 55.1$ & $94.9 \pm 11.1$ & $97.4 \pm 7.1$ & $76.6 \pm 19.5$ \\
\hline
\end{tabular}

DLCO Single breath carbon dioxide diffusion capacity; FEV Forced expiratory volume in $1 \mathrm{~s}$; FVC Forced vital capacity: AV Respiratory volume TLC Total lung capacity 


\section{DLCO \%}

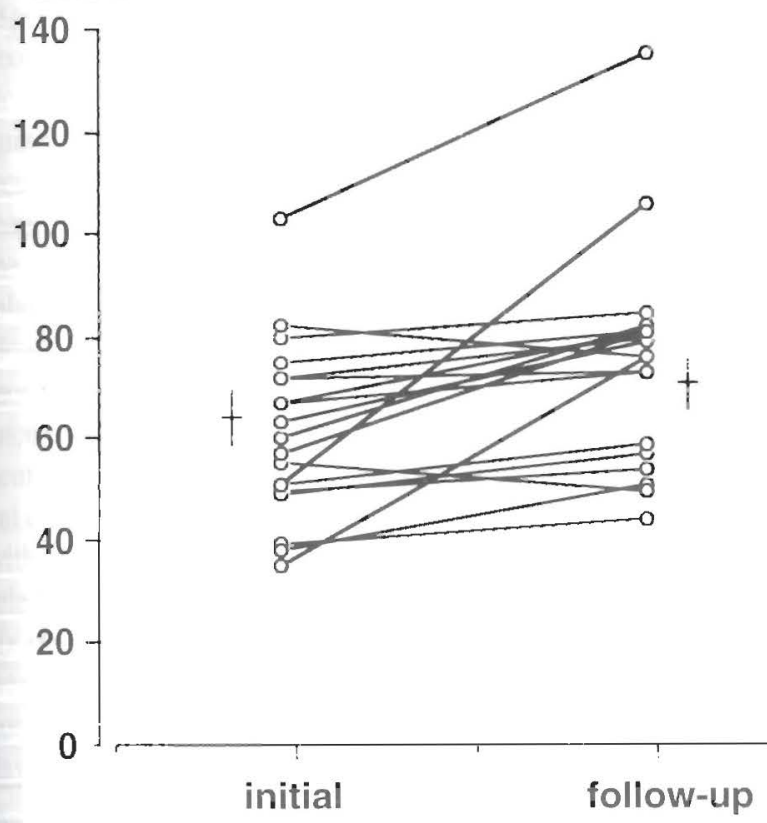

\section{DLCO \%}

140

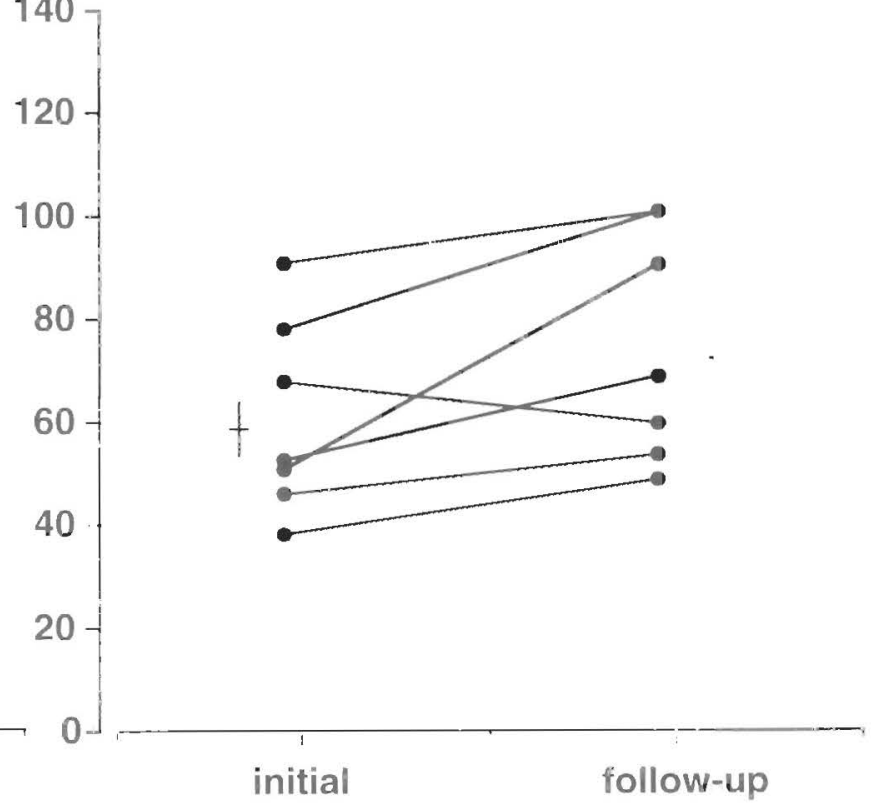

Off contact group

\section{Prednisone group}

Figure 1) Individual results and means $\pm S D$ for subjects of both treatment groups at diagnosis and one month later. Lung diffusion capacity (DLCO) increased in most subjects and the mean increase was similar for both groups. Prednisone group P=11.0002; contact avoidance (off contact) group $P=0.04$

\section{RESULTS}

Nineteen subjects received corticosteroid treatment and continued their work on the farm while the remaining nine were treated by contact avoidance only. Subjects in both groups were of similar age, one ex-smoker was in each tratment group, and of the five females, three were in the contact avoidance group and two were in the prednisone group. All subjects improved with either form of treatment and all subjects reported an improvement in their dyspnea. After one month, 10 patients reported that they were now back to normal and no longer dyspneic; five were in the contact avoidance group and five were in the corticosteroid treatment group. All fever and malaise resolved by the second visit. At diagnosis, inspiratory crackles were heard in 24 subjects; after one month these physical signs had disappeared in 17 ( 10 in the corticosteroid treated group, seven in the contact avoidance group). Results of pulmonary functions at diagnosis and at follow-up are presented in Table I. Both groups were initially similar. Lung function improved in most subjects with either treatment. DLCO was the lung function parameter that was initially most abnormal. It significantly improved in each group. Figure I shows individual changes in DLCO for all subjects who were treated with prednisone and seven of the nine who ceased contact. Follow-up data for this parameter were not available in two subjects. Forced expiratory volume in $1 \mathrm{~s}\left(F E V_{1}\right)$ and forced vital capacity (FVC) also significantly improved in the prednisone group $(\mathrm{P}=0.004$ and 0.000$)$ s. respectively). The improvement in these parameters for the contact avoidance

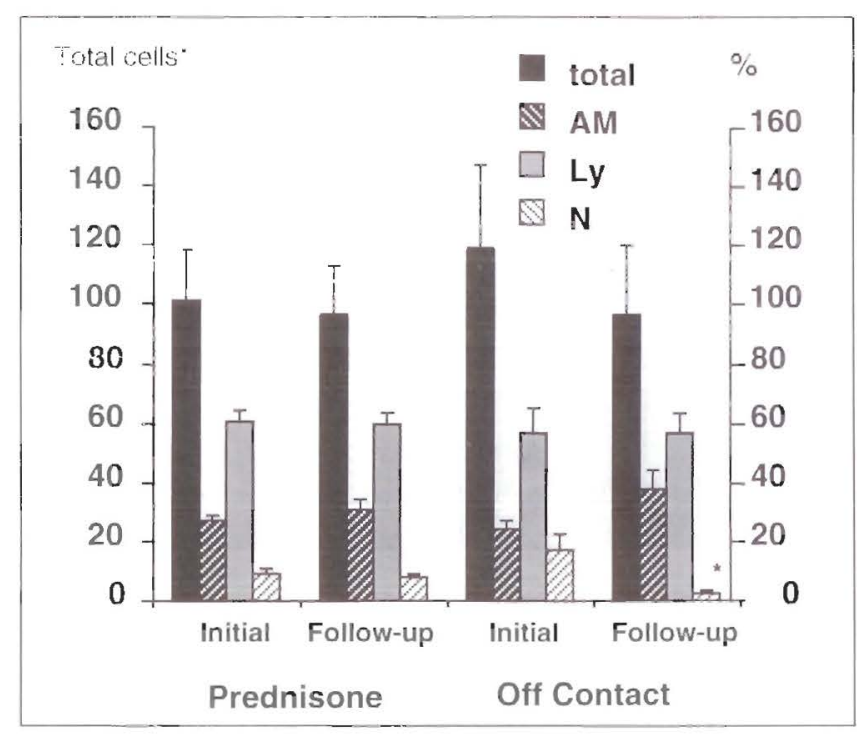

Figure 2) Mean $\pm S E M$ data for the total cells and differentials recovered by bronchoalveolar lavage for each group of subjects and both at diagnosis and after one month of treament with either corticosteroids (Prednisone) or contact avoidance (Off Contact). Both groups were initially similar and the only cell type that significantly changed was the neutrophils in the contact avoidance group. *To obtain total cells, multiply the graphed values by $10^{6}$. AM Alveolar macrophages: Ly Lymphocyes; $N$ Neutrophils

group did not reach statistical significance (each $\mathrm{P}=0.08$ ). This lack of significance probably relates to the smaller number of subjects in this group. Total lung capacity and 


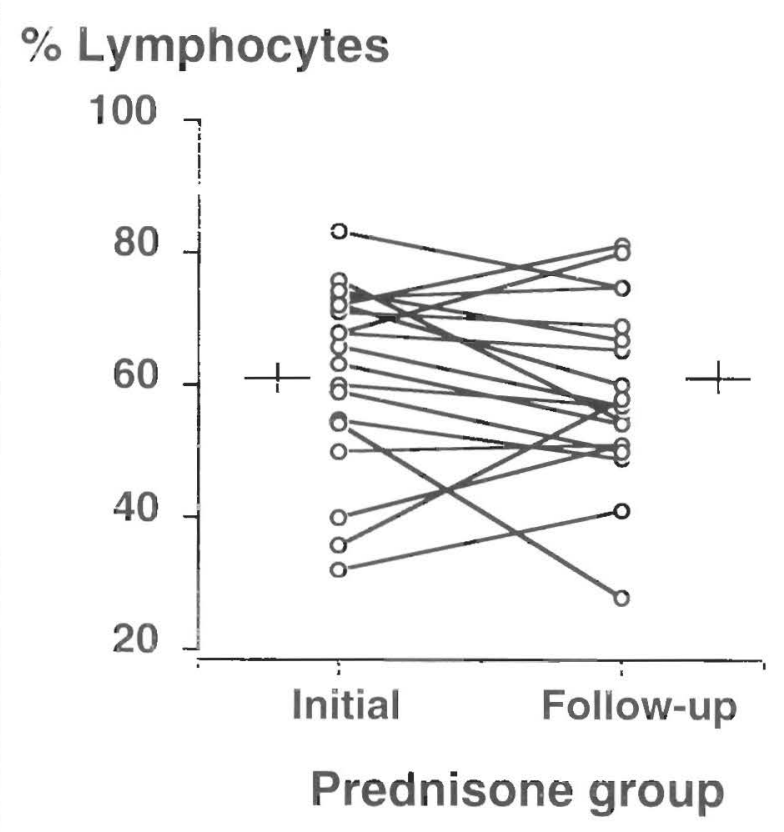

\section{$\%$ Lymphocytes}

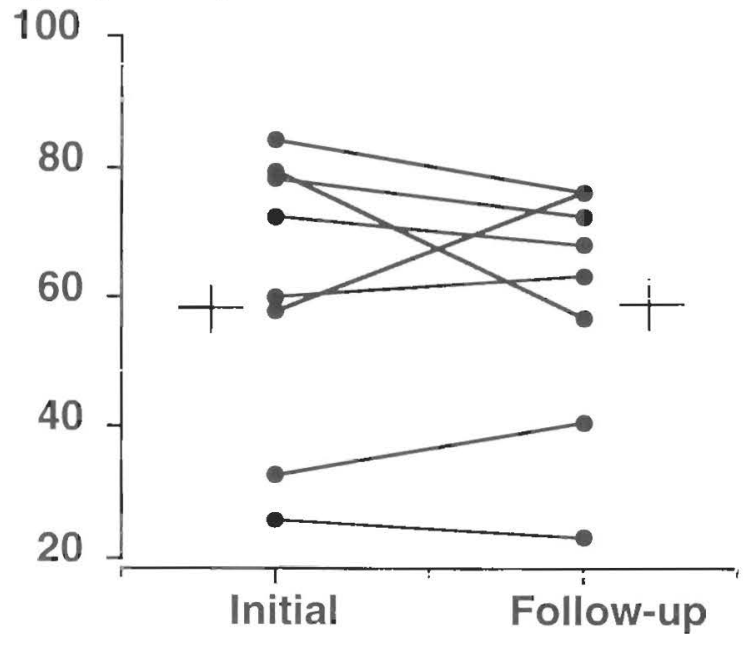

Off contact group

Figure 3) Individual and mean \pm SEM percentage lymplucytes in the lavage fluid for both groups of subjects at diagnosis and after one month of treatment. Note the similarity in both groups and the relative lack of changes in thesc cells after one month

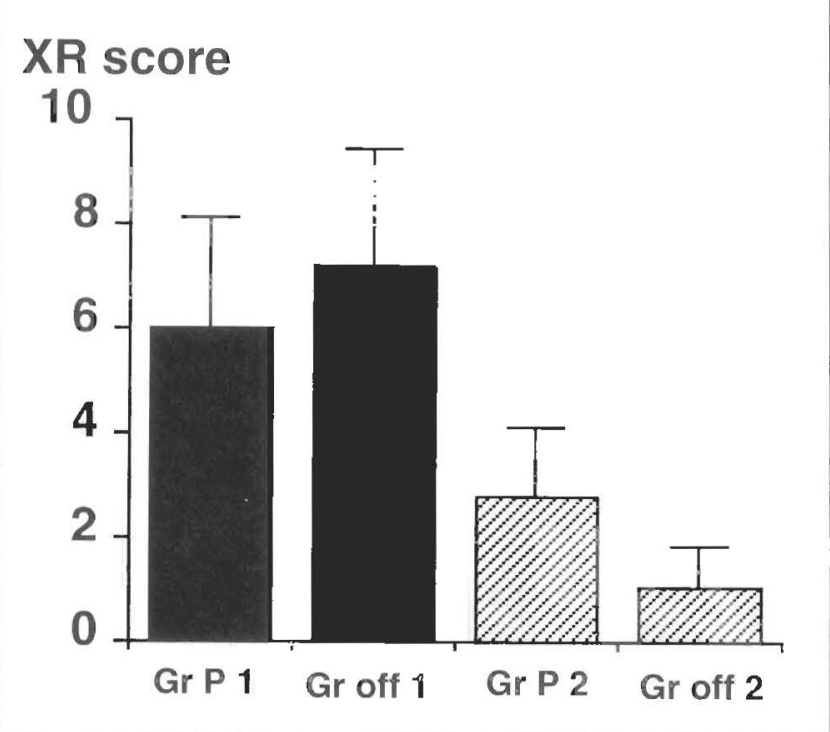

Figure 4) Mean $\pm S E M$ chest radiograph (XR) scores before and after treatment for the prednisone treated group (PI and P2) and the contact avoidance group (off I and off 2). Chest radiograph infiltrations improved in both groups

residual volume were not significantly changed by either treatment.

A similarity was seen in both groups for the BAL cells (total, lymphocytes and alveolar macrophages) (Figure 2). However, neutrophils were higher in the contact avoidance group. Repeat BAL showed a mild decrease in BAL cells after one month, similar in those who had received prednisone and in those treated by contact avoidance only (Figure
2). Again, the only BAL cell that differed was the neutrophil. with a significant decrease in the contact avoidance group but no changes in the corticosteroid treatment group. Individual values for the percentage of lymphocytes at diagnosis and at follow-up for each group are shown in Figure 3. These cells were not significantly different one month after treatment from the initial values. The percentage BAL fluid return was similar for both study groups at the first $150 \pm 12 \%$ for the prednisone group and $50 \pm 13 \%$ for the contact avoidance group) and at the follow-up studies $(57 \pm 1 \mathrm{l} \%$ : versus $55 \pm 15 \%$. respectively); this difference was not statistically significant $(\mathrm{P}=0.07)$.

Chest films at diagnosis and at one month follow-up were available for review in 22 subjects. Initial radiographic scores were similar in both groups. One month later scores had decreased significantly and remained similar in both group. (Figure 4). The only correlation between variables was between lung diffusion capacity and chest radiographic (CXR) score at diagnosis $(\mathrm{P}=0.0014)$ (Figure 5). There were no correlations between any of the BAL cells parameters and lung function or CXR scores at either diagnosis or at one month follow-up, whether tested for the group as a whole or for the two groups separately.

\section{DISCUSSION}

The present study shows that relatively small doses of corticosteroids and contact avoidance are both effective in the initial treatment of acute hypersensitivity pneumonitis. Although all subjects improved by either treatment and some had actually returned to normal, BAL, after one month of corticosteroids or contact avoidance, was still markedly abnormal, with a persisting lymphocytic alveolitis. Although 
side effects were minimal. one would obviously recommend contact avoidance when possible; however. in certain cases, especially farmers. contate avoidance was often socioeconomically impractical. In such circumstances. corticosteroid treatment seens to be a valid alternative. The often yuoted recommended daily dose of corticosteroids in the tratment of acute hypersensitivity pneumonitis is higher than the $20 \mathrm{mg}$ per day given in this study $(5)$; in one review the dose is not specified (10). We have not compared the relative effects of two doses of corticosteroids on outcome. However, since $20 \mathrm{mg}$ daily gives a similar improvement in most of the clinical parameters evaluated as contact avoidance (all subjects who continued contike had no recurrence of acute febrile symptoms and noted improvenent in their chinical condition), we believe it is reasonable to treat this disease with lower doses rather than higher. This maly be especially relevant since farmers often require corticosteroids for up to six months every winter that their disease flairs up. Another way to decrease further the potential effects of long term corticosteroid therapy maly be 10 give the drug on alternate days (11) or eventually usc targeted delivery methods (12).

We do not know whether the long term outcome woukt differ between the two groups. Based on previous studies it is very unlikely that cither form of initial treatment would significantly modify outcome; corticosteroids do not improve long term outcome $(4,5)$. A long term outcome study is impossible for our group of subjects. Most of those who chose to cease contact have done so on a permanent basis and their outcome may he different because of that decision, not because of the initial treatment. Farmers who stayed on the farm are for the most part still in contalet and may have hald or may eventually have recurences, either alcute or subalcutc in nature.

Subjects were not randomired into either treatment arm for reasons already discussed. The groups, although unequal in number and in the proportion of farmer's lung, were similar in terms of all clinical parameters compared. Therefore, we believe that selection bias was not responsible for the relatively small differences in the outcome of each group.

An interesting observation in this study is the persistence of a high intensity lymphocytic alveolitis after one month, despite the marked clinicil, functional and radiological improvement. Since the percentages of lymphocytes were similar in both studies, we do not belicve that the higher BAL fluid return was responsible for this finding. This finding corroborates our previous studies showing that BAL lymphocytosis persists in farmers with a history of farmer's lung, especially those who stay on the farm and in asymptomatic seropositive farmers (13). Perhaps variables other than the number of lymphocytes in the BAL can differentialte the two (14-16).

One significant difference between the two groups both at diagnosis and especially in response to the treatment arm was the level of neutrophils in the BAL, fluid. The initial higher number of these cells could be explained by the fact that all cases of humidifier lung and bird tancier's lung were in this group. Perhaps they were more acutely in contact with the

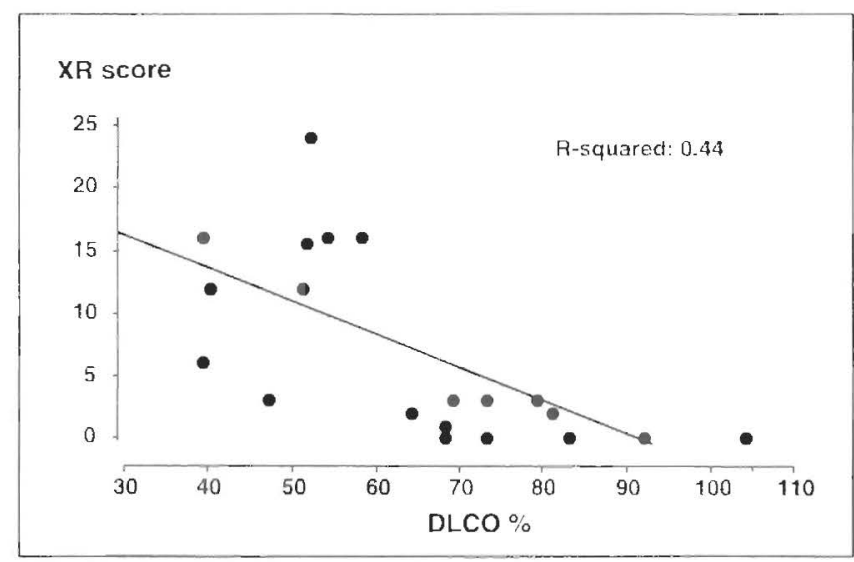

Figure 5) Corrctution between chest radiograph (XR) scorc and carhon dioxide hung diffusion capacity (DLCO) at diagnusis for all subierts whoth groups $(P=0.001+)$

offending environment. The acuteness of hypersensitivity pneumonitis is associated with BAL neutrophilia (17). The persistence of relatively high numbers of neutrophils aller one month of steroid treatment was surprising, however, especially since all of these subjects were clinically improved and since these cells returned to normal values in the off contact group. Two hypotheses to explain this finding are that continued exposurc contributed lowards maintaining the neutrophilia or that corticosteroids were responsible for this finding. Corticosteroids are known to increasc blood leukocytosis by demarginating these cells. $A$ similar mechanism may take place in the lungs.

\section{CONCLUSIONS}

Although BAL findings remain abnomal, both contact avoidance and low dose corticosteroids are clfective in controlling symptoms and improving Iung function in actite hypersensitivity pucumonitis. Contact avoidance remalins the obvious treatment when feasible. Based on the narked inprovement in our patients in either arm of this study, it is unlikely that higher doses of corticosteroids or the addition of corticosteroids in subjects who cease contact would significantly add to the initial treatment of the disease.

\section{REFERENCES}

I. Cormier Y, Schuyler M. Hypersensitivity pneumonitis. In: Bone RC, cd. Textbook of Pulmoniry Medicine, Vol 2 Part M: Interstitial Lunge Disease. St louis: Mosby Ycar Book. [9) $2: 1-9$.

2. Fink JN. Clinical features of hypersensitivity pnemononitis. Chest 1986;89: 193S-5S.

3. Richerson HB, Bernstein IL, Fink JN, et at. Guidelines fur the clinical evaluation of hypersensitivity pneumonitis. J Allergy Clin Immunol [989:84:839-44.

4. Kokkarinen JI, Tukianen HO, Terho EO. Effict of corticosteroid treatment on the recovery of pulnunary function in farmer's lung. Am Rev Respir Dis 1992; 1 45:3-5.

5. Mönkäre S, Haahtela T. Farmer's lung - a 5-year follow-up ol eighty-six patients. Clin Allergy 1987; 17: 143-51.

6. Chemlik F, Dolico G, Reed CE, Dickie H. Farmer's lung. J Allergy Clin Immunol 1975;54:180-8.

7. Cotes JE, Hall M. The transfer factor for the lung, normal 
values in adults. In: Arcangeli P. ed. Normal Values For Respiratory Functions in Man. Torino: Pan Minerva Medica 1970:327-43.

8. Grimby G, Söderholm B. Spirometric studies in normal subjects. III. Static lung volumes and maximum voluntary ventilation in adults with a note on physical fitness. Acta Med Scand 1963:173:199-206.

9. Cormier Y, Bélanger J, Tardif A. Leblane P, Laviolette M. Relationship between radiographic changes, pulmonary function, and bronchoalveolar lavage fluid lymphocytes in farmer"s lung disease. Thorax 1986;41:28-33.

10. Fink JN. Hypersensitivity pneumonitis. J Allergy Clin Immunol 1984:74: [-9.

11. MacGregor RR, Sheagren IN, Lipsetl MD, Wolff SM. Alternate day prednisone therapy. Evaluation of delayed hypersensitivity response, control of disease and steroid side effects. N Engl J Med 1969:280:1427-31.

I2. Tremblay GM, Térrien M-H. Assayag E, Cormicr Y. I iposomal deximidlatsone effectiveness in the treatmicul of hypersensitivity pneumonitis in mice. Eur J Clin Invest [993:23:656-61.

13. Leblane P, Bélanger J, Laviolette M, Cormier Y'. Farmer 's lung disease: relationship between continued exposure, alvenlitis. and clinical status. Arch Intern Med 1986:146:153-7.

I.t. Jouanel P, Motta C, Brun J, et al. Phospholipids and microviscosity in broncho-alveolar lavage fluid from control subjects and from patients with extrinsic allergic alveolitis. Clin Chimica Acta 1981:115:2 I 1-21.

15. Larsson K, Eklund A, Malmberg P, Bjermer L, Lundgren R. Belin L. Hyaluronic acid (hyaluronan) in BAL fluid distinguishes farmers with allergic alveolitis from those wit! asymptomatic alveolitis. Chest 1992;101:109-14

I (1. Trentin L, Marcer G, Chilosi M, el al. Longitudinal sludy w! alveolitis in hypersensitivity pneumonitis patients: an immunologic evaluation. J Allergy Clin Immunol 1988;82:577-85.

17. Fournier E, Tonnel AB, Gosset Ph, et al. Early neutrophil alveolitis after antigen inhalation in hypersensitivity pneumonitis. Chest 1985:88:563-6. 


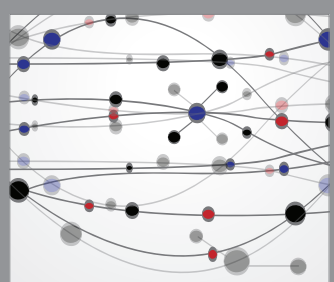

The Scientific World Journal
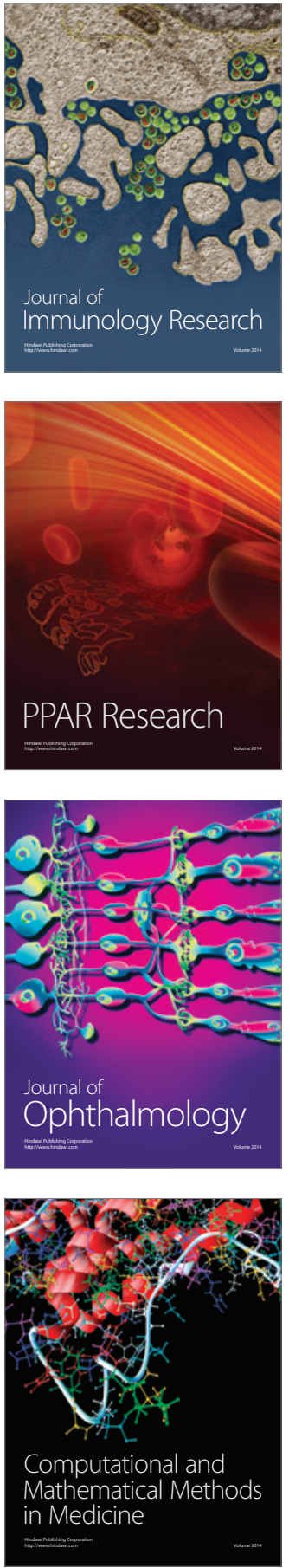

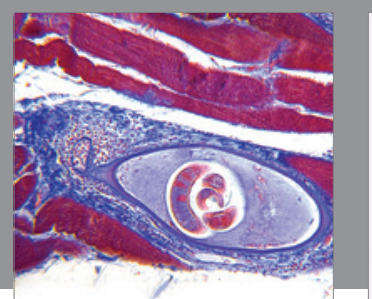

Gastroenterology Research and Practice

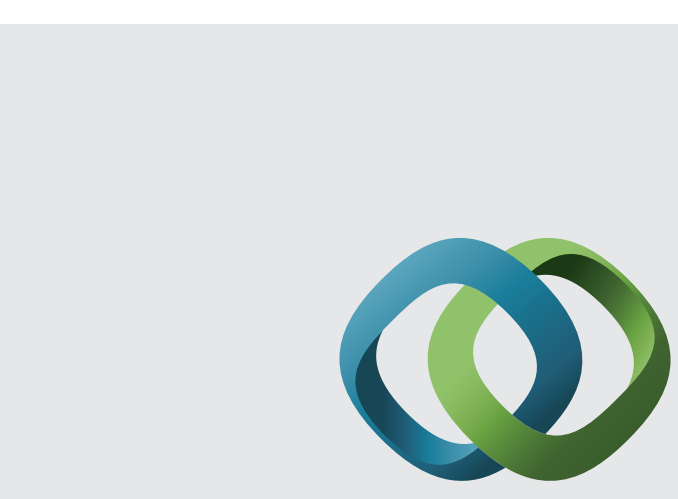

\section{Hindawi}

Submit your manuscripts at

http://www.hindawi.com
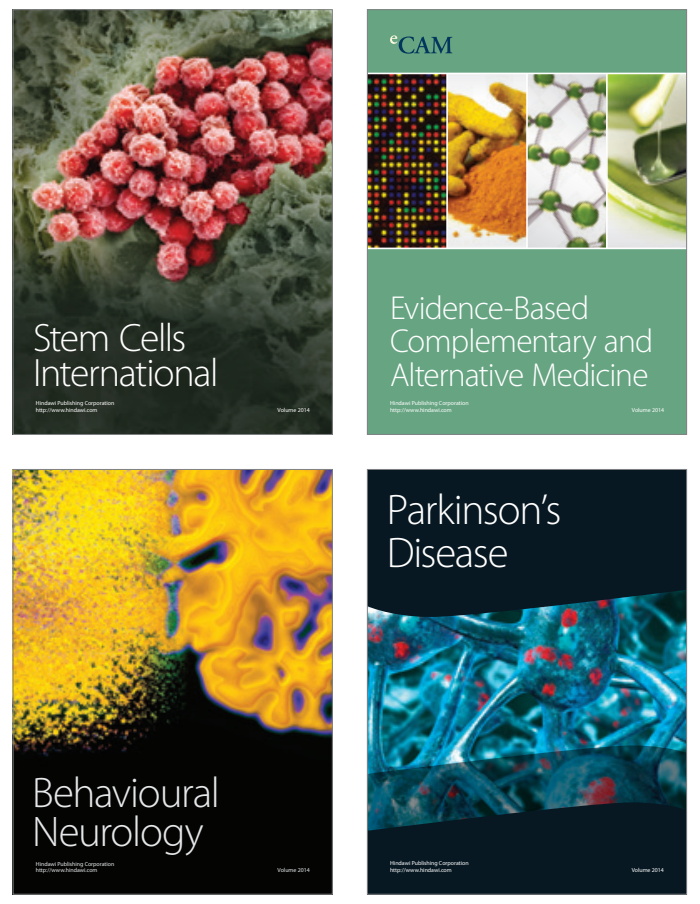
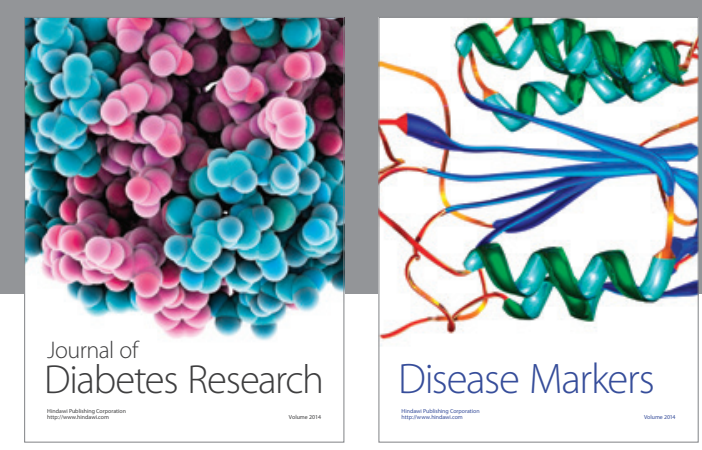

Disease Markers
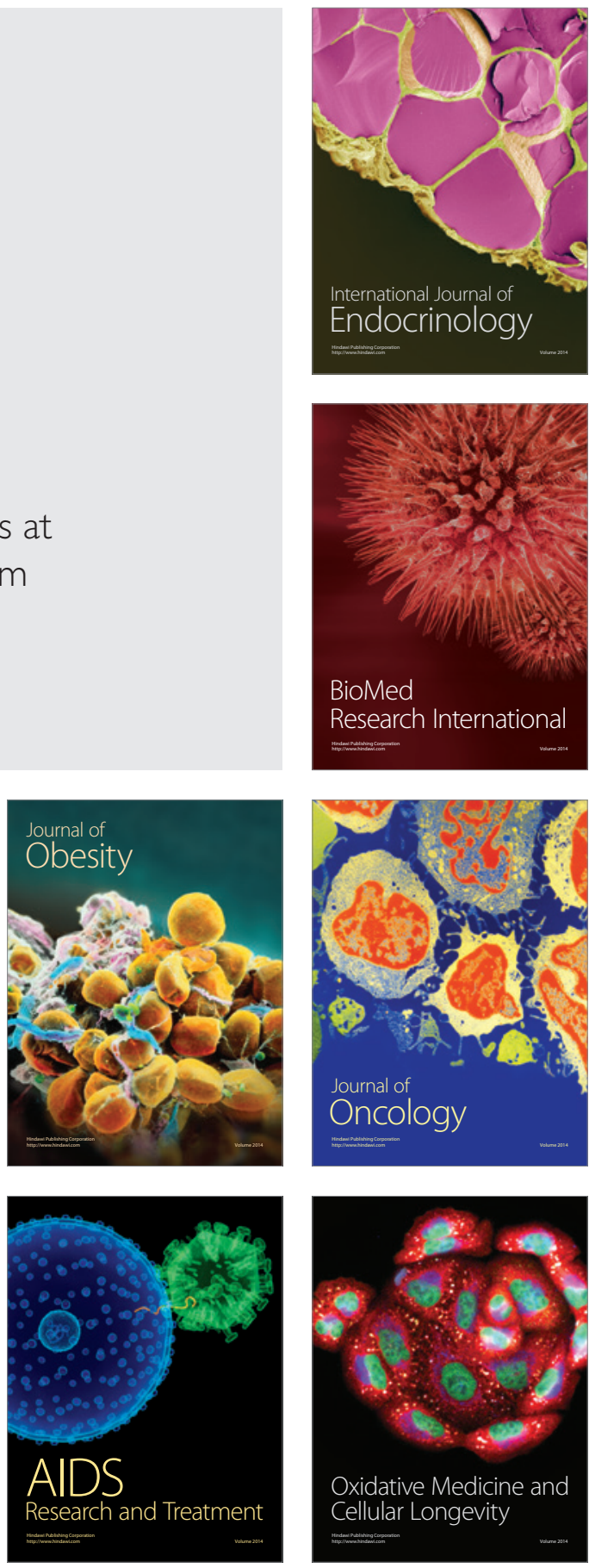